\title{
Health Manpower Development(HMD) Corner Stone of Improving National Health System
}

National health system is the fundamental structure regarding community health needs and responding to them. Many elements are necessary to be classified for better set up of national health system. Some of them are as follows:

1. Vision of policymakers about public health: It is important to be well aware about policy makers' point of view and their responsibility about the health, its expenditure and sharing of the cost by public, charity section and out of packet. Knowledge and attitude of policy makers are important issues that should be taken into careful consideration.

2. Geography: location of the country not only because of geographical pattern but the political, cultural and social elements, especially problems such as desertation of non-arable land also are important status.

3. Population: the size of the population and important figures should be available such as age composition with emphasis on the important age- groups (e.g. under 15 and over 60 - 65 years old)

4. Economic level: the gross domestic products (GDP), and /or gross national products (GNP), and the Gini coefficient. Social justice in distribution of income among the population groups, the main source of wealth, such as mining (specially oil products), agriculture, industries, new technology, software or/and hardware, etc.

5. Urbanization and its trend.

6. Literacy and its proportion between men and women, and the quality of knowledge. The mean of social literacy especially among women.

7. Administration units: member of provinces, countries, and the population of the cities.

8. Religion: the type of religion and their frequency, the size of followers and their life style regarding the religious rules.

9. Major health indicators such as life expectancy, death and birth rate, maternal mortality, infant and neonate mortality, the case of death, the important health problems and many other health indicators.

These are some of the general backgrounds for reviewing health manpower development that I will discuss more in the future issues.

\author{
Mohammad E. Akbari \\ Professor of Surgical Onclogy \\ Chairman \& Editor in Chief
}

Copyright (C) 2015, Iranian Journal of Cancer Prevention. This is an open-access article distributed under the terms of the Creative Commons Attribution-NonCommercial 4.0 International License (http://creativecommons.org/licenses/by-nc/4.0/) which permits copy and redistribute the material just in noncommercial usages, provided the original work is properly cited. 